\title{
Population dynamics and expansion of Crangonyx pseudogracilis, a potentially invasive amphipod
}

\author{
Daniela Correia*, Filipe Banha, Mafalda Gama and Pedro M. Anastácio \\ MARE - Marine and Environmental Research Centre, Departamento de Paisagem, Ambiente e Ordenamento, Universidade de Évora, \\ Rua Romão Ramalho, no. 59, Évora 7000-671, Portugal
}

Received: 11 September 2020 / Accepted: 4 January 2021

\begin{abstract}
One of the main drivers of biodiversity loss is the introduction of exotic invasive species. In 2011, an abundant population of Crangonyx pseudogracilis, a freshwater amphipod native to North America, was detected in Portugal. This study allowed us to better understand its biology, analysing the population dynamics in a temporary river and a small lake for one year, and to follow its expansion. Our results showed that this species reproduces in the temporary river during most of the year, but in the lake only from March to July. Amphipod density decreases from May to October and increases from November to April. As usual, females were larger than males, but the proportion of females was higher than males at both sampling locations. Finally, we noticed a great increase in C. pseudogracilis distribution area in relation to what was observed in 2014 , with a diffusion coefficient of $2495.27 \mathrm{~km}^{2} /$ year and a spread rate of $26 \mathrm{~km} /$ year. However, no overlap was yet detected between native and exotic amphipod species.
\end{abstract}

Keywords: Biological invasions / dispersion / expansion / recruitment period / population structure

\begin{abstract}
Résumé - L'introduction d'espèces exotiques envahissantes est l'un des principaux moteurs de la perte de biodiversité. En 2011, une population abondante de Crangonyx pseudogracilis, un amphipode d'eau douce originaire d'Amérique du Nord, a été détectée au Portugal. Cette étude nous a permis de mieux comprendre sa biologie, d'analyser la dynamique populationnelle dans une fleuve temporaire et un petit lac pendant un an, et de suivre son expansion. Nos résultats ont montré que cette espèce se reproduit dans le fleuve temporaire pendant la plupart de l'année, mais dans le lac seulement de mars à juillet. La densité des amphipodes diminue de mai à octobre et augmente de novembre à avril. Comme d'habitude, les femelles étaient plus grandes que les mâles, mais la proportion de femelles était plus élevée que celle des mâles aux deux endroits d'échantillonnage. Enfin, nous avons constaté une forte augmentation de la surface de distribution de $C$. pseudogracilis par rapport à ce qui a été observé en 2014, avec un coefficient de diffusion de $2495,27 \mathrm{~km}^{2} /$ an et un taux de propagation de $26 \mathrm{~km} / \mathrm{an}$. Cependant, aucun chevauchement n'a encore été détecté entre les espèces indigènes et l'espèce exotique d'amphipodes.
\end{abstract}

Mots clés : Invasions biologiques / dispersion / expansion / période de recrutement / structure de la population

\section{Introduction}

Freshwater ecosystems are biodiversity hotspots with diverse communities, some of which are very sensitive to environmental and anthropogenic changes (Aylward et al., 2005). These ecosystems, as well as their communities, are essential for human survival, for example as a food resource, to allow nutrient recycling and maintaining water quality at the same time (Aylward et al., 2005). In freshwater ecosystems, amphipods have a fundamental role, acting as nutrient and energy conductors for higher trophic levels (Väinölä et al.,

\footnotetext{
${ }^{*}$ Corresponding author: dfpc.21@gmail.com
}

2007). Currently in Portugal, there are three native epigean species of freshwater amphipods: Echinogammarus meridionalis Pinkster, 1973, Echinogammarus simoni Chevreux, 1894 and Echinogammarus lusitanus Schellenberg, 1943 (Pinkster, 1973, 1993; Dobson, 2012).

One of the main factors of biodiversity loss is the introduction of exotic species in freshwater ecosystems. This promotes predation of native species, competition between non-native and native species, hybridization, alteration of the physical and chemical habitat properties, changes in food webs, bioaccumulation of toxic substances and disease and parasites transmission (Guerra and Gaudêncio, 2016). In the case of amphipods, it will affect nutrient recycling and energy 
transfer to higher trophic levels (Piscart et al., 2011; Jourdan et al., 2016), sometimes causing the total elimination of native populations. According to Katsanevakis et al. (2013), to implement effective measures for the prevention, control, and management of invasive species, it is fundamental to know the biological and ecological characteristics of these, as well as to monitor their occurrence, vectors of introduction and geographical expansion.

In 2011, an abundant population of Crangonyx pseudogracilis Bousfield 1958 was detected in the centre of Portugal and very far from the nearest European invaded area (Grabowski et al., 2012). This freshwater amphipod from the Crangonyctidae family is native to North America, and can be found for example in Lake Charles, Louisiana (Slothouber Galbreath et al., 2009). In 1939 it invaded Western Europe through England (Crawford, 1937; Tattersal, 1937; Gledhill et al., 1993), spreading to Netherlands (Pinkster et al., 1980; Zhang and Holsinger, 2003), Wales (Gledhill et al., 1993) Scotland (Gledhill et al., 1993), Belgium (Pinkster et al., 1980), Germany (Silfverberg, 1999), Finland (Silfverberg, 1999), Ireland (Holmes, 1975; Dick et al., 1999) and finally in 2011 it was detected in Portugal (Grabowski et al., 2012). This was the first exotic freshwater amphipod detected in the Iberian Peninsula (Grabowski et al., 2012).

Crangonyx pseudogracilis can be found mainly in streams, rivers and lakes with slow flow conditions (Holland, 1976; Zhang and Holsinger, 2003; Josens et al., 2005). Despite being a freshwater species, it can tolerate some salinity (Chloride: 250-350 mg/L) (Slothouber Galbreath et al., 2009). These, when compared to other Gammarids, present a different locomotory behaviour, as they swim vertically and usually occupy the most polluted areas of the streams (Gama et al., 2017). According to Hynes (1955), Sutcliffe and Carrick (1981), Pinkster and Platvoet (1983) and Dick et al. (1998, 1999), this exotic species reproduces faster than the native epigean species present in Portugal (e.g. Echinogammarus) as females reach sexual maturity in 2-3 months, having a longevity that can reach up to two years, being able to produce up to eight broods during this period.

The introduction of this species in Europe may have resulted from the transport of live fishes and/or aquatic plants, on boats (Zhang and Holsinger, 2003), or from the timber trade (Maitland and Adams, 2001). Crangonyx pseudogracilis dispersion after the introduction is associated with the previously mentioned human vectors or other activities like fishing (Banha and Anastácio, 2015) but there are other possibilities, such as on the plumage and legs of birds (Rachalewski et al., 2013) or through aquatic migration corridors. However, in the Iberian Peninsula, the latter is limited by the reduced number of artificial channels that interconnect the river basins (Rachalewski et al., 2013).

In Portugal, Crangonyx pseudogracilis was found in the Tagus river basin namely in some south tributaries (Banha et al., 2018). Crangonyx pseudogracilis is not yet legally considered an invasive species, however, there are native species of amphipods that might be threatened by the arrival of this exotic species. In Portugal, there are some populations of the genus Echinogammarus, endemic to the Iberian Peninsula, in several river basins in the North and West part of Portugal, which are adjacent to the currently invaded Tagus basin.
The objectives of this study are to monitor the expansion of an exotic freshwater amphipod (Crangonyx pseudogracilis) in Portugal, identifying overlapping distributions with native amphipods and to analyse its population dynamics in a temporary river pool and a natural lake. The analysis of the current distribution area of this amphipod in Portugal, and how it has changed since the last fieldwork assessment (2011), will allow us to estimate its diffusion coefficient. Population structure and population dynamics analysis will provide important information to estimate the invasive potential of the species.

\section{Materials and methods}

\subsection{Field sampling for population dynamics}

In order to study the population dynamics of Crangonyx pseudogracilis, samples were taken in two locations (Ferrarias, $38^{\circ} 54^{\prime} 08.77^{\prime \prime} \mathrm{N}, 8^{\circ} 15^{\prime} 39.40^{\prime \prime} \mathrm{W}$; and Coruche, $38^{\circ} 57^{\prime} 12.06^{\prime \prime} \mathrm{N}$, $8^{\circ} 31^{\prime} 8.95^{\prime \prime} \mathrm{W}$ ) (Fig. S1), that are $23.09 \mathrm{~km}$ away from each other), where the presence of this species had already been detected in 2011. These two locations were selected to represent two distinct invaded aquatic environments. Ferrarias is in the Divor, a temporary river, but due to the occurrence of a summer pool water is present at this location throughout all year. This river has a $1425.4 \mathrm{~km}^{2}$ hydrographic basin and a maximum length of $72 \mathrm{~km}$, and it is a tributary of the Sorraia river, within the Tagus river basin (Ferreira, 1994). At this location, the river bottom is mainly sandy, and riparian vegetation is composed of Salix spp., Fraxinus angustifolia and Alnus glutinosa. Submerged plants were absent but macrophytes like Thypha spp. and Cynodon dactylon were present. Coruche is also located within the same river basin and corresponds to a natural lake with approximately $2 \mathrm{~km}^{2}$. This small lake is surrounded by agricultural crops such as maize, with Salix sp. in the margins as well as the invasive species Arundo donax which covers large areas. Thypha spp. were also present. The invasive species Myriophyllum aquaticum covers almost all the water surface.

Samples were collected between May 2016 and June 2017 , with a $1 \mathrm{~mm}$ mesh dip net and stirring the substrate. The total sampled area was always constant, $1.5 \mathrm{~m}^{2}$ for each location, that is, three replicates of $0.5 \mathrm{~m}^{2}$, allowing for density comparisons. To ensure the collection of all individuals in the sampled area, the same effort of ten minutes per replicate was always used. This was previously tested and considered enough to collect all individuals in that sampling area size. Samples were kept in bottles containing $96 \%$ ethylic alcohol, which also allows for DNA preservation, in case further genetic studies are needed. For each location during the sampling period (14 months), physical and chemical variables, such as $\mathrm{pH}$, dissolved oxygen, conductivity, temperature was monitored using a portable WTW field probe model MultiLine P4 and a Hanna model HI 93703-11 was used for turbidity measurements. One Tinytag Aquatic 2 Datalogger model TG-4100 was left at each location, but the one in Ferrarias disappeared. Microhabitat characteristics, such as water depth, type of vegetation, type of substrate and speed of water flow were also recorded (Grabowski et al., 2012). 


\subsection{Field sampling for distribution}

To know the current distribution of Crangonyx pseudogracilis, in Portugal, samples were taken during 2019 (June, July and October). These included locations where the species was not found in 2011 (Tagus river Basin) but the sampling was expanded to locations provided by the Administration of the Tagus and West Hydrographic Region (ARHTO) where amphipods were previously found but not identified. A total of 57 locations were sampled in the Tagus river basin and Western Portugal (small river basins). The physical and chemical variables were measured, and microhabitat characteristics of each site were recorded, as previously described. All sampling sites contained water throughout the year (Banha et al., 2018). The sampled area varied from place to place, since in this case, the purpose was only to assess the presence of amphipods in each location during a maximum period of one hour. In the locations where amphipods were found, they were collected using a $1 \mathrm{~mm}$ mesh dip net and stored in bottles containing $96 \%$ ethanol, for further identification in the laboratory as native or exotic amphipods in a process similar to above.

\subsection{Population dynamics sample analyses}

An OLYMPUS SZ40 Stereo Zoom Microscope was used to identify the sex of each individual, count the number of eggs and/or embryos present in fertilized females and measure each amphipod length. Mature reproductive females have a pouch with eggs and/or embryos in the abdomen. Males have calceoli, which are clavate structures, in the second pair of antennas. The number of eggs and/or embryos was counted whenever detected (Banha et al., 2018). Amphipods were measured head to telson (Banha et al., 2018) using a Leica EC3 video camera for image capture, which were analysed and measured using IC Measure software.

\subsection{Species distribution sample analyses}

The samples collected in 2019 to assess the distribution of Crangonyx pseudogracilis, were analysed in the laboratory, to identify whether the amphipods were native (e.g. Echinogammarus meridionalis), or non-native (Crangonyx pseudogracilis). This identification was made with an OLYMPUS SZ40 Stereo Zoom Microscope and was based on the identification key "Identifying Invasive Freshwater Shrimps and Isopods" by Dobson (2012). For Crangonyx pseudogracilis, the sex of each individual and the number of eggs and/or embryos were registered. All the specimens were photographed with a Leica EC3 video camera, attached to an OLYMPUS SZ40 Stereo Zoom Microscope.

\subsection{Population dynamics statistical analysis}

One $\mathrm{mm}$ size classes were created, starting at $1 \mathrm{~mm}$ and ending at $16 \mathrm{~mm}$, and size-frequency histograms were produced for males and for females, at each location and sampling date. FiSAT II Software (version 1.2.2, FAOICLARM) was used for modal progression analysis of sizefrequency distribution data (Anastácio et al., 2018). The initial analysis was made using the Bhattacharya method
(Sparre et al., 1992) and then the Normsep method with the Simplex algorithm applied (Anastácio et al., 2018). For each of the cohorts, the standard deviation and average size of males and females were calculated. With these measures, scatter plots were created, where it was possible to identify cohorts and calculate the growth rate in some of them. Only two cohorts could be followed since these were the only ones for which there was a clear temporal sequence along several consecutive sampling occasions, with an increase in the mean size of the cohort.

In order to find out if the males and females of each of the sites were of the same size, the Independent samples t-test (Zar, 1999) was used, comparing separately the size of males and females in each location. To compare the proportion of females and males in each month for each location separately during the sampling period, the Chi-Square test was used. The Wilcoxon test was used to compare the proportion of females between the sampled locations (Ferrarias and Coruche). The Wilcoxon test was also used to compare each of the physical and chemical variables (dissolved oxygen, $\mathrm{pH}$, conductivity, turbidity, temperature, water depth) between sampling sites. SPSS software (version 24.0) was used for these statistical tests. Regarding the physical and chemical variables, boxplots were created for each of the sampled locations, using GraphPad Prism software (version 5.01).

\subsection{Species distribution mapping}

With the data obtained and using the ArcGIS Software v. 10.6, Crangonyx pseudogracilis distribution maps were created, thus updating the existing information. These maps contain a total of 75 points from north to south of Portugal, with emphasis on the Tagus river basin and West zone, which was where our sampling was focused. Of these 75 points, 10 of them correspond to points where the exotic species had already been detected in 2011 and 18 points correspond to samples that were provided to us by other research teams, where amphipods were present. In order to know the current area of the species and what it occupied in 2014, the minimum convex polygon area was calculated in ArcGIS software. From the difference in the area occupied by the species in 2014 and now in 2019 it was possible to calculate the speed of the invasion of Crangonyx pseudogracilis, namely its diffusion coefficient (D), expressed as $\mathrm{km}^{2}$ /year (see for ex. Lockwood et al., 2007 for further details). Measuring the distance from new points (2019) to the nearest old points (2014), it was possible to estimate the mean Spread rate $(c)$ in $\mathrm{km} /$ year. Finally, using the equation $c=2 \sqrt{r D}$ it was possible to estimate the intrinsic growth rate (r) of the population (see Lockwood et al., 2007 for more details).

\section{Results}

\subsection{Population dynamics in Ferrarias and Coruche}

In Ferrarias the total number of individuals captured during the sampling period was 1440 , with a mean density from 14 to 680 amphipods $\mathrm{m}^{-2}$ (Fig. 1). Regarding Coruche the total number of individuals captured between May 2016 and June 2017 was 1099 , with a mean density from 22 to 342 amphipods $\mathrm{m}^{-2}$ (Fig. 1). Densities are clearly higher in Coruche during winter and spring. A somewhat similar pattern of abundance occurs in Ferrarias, but with a distinct peak in August. 

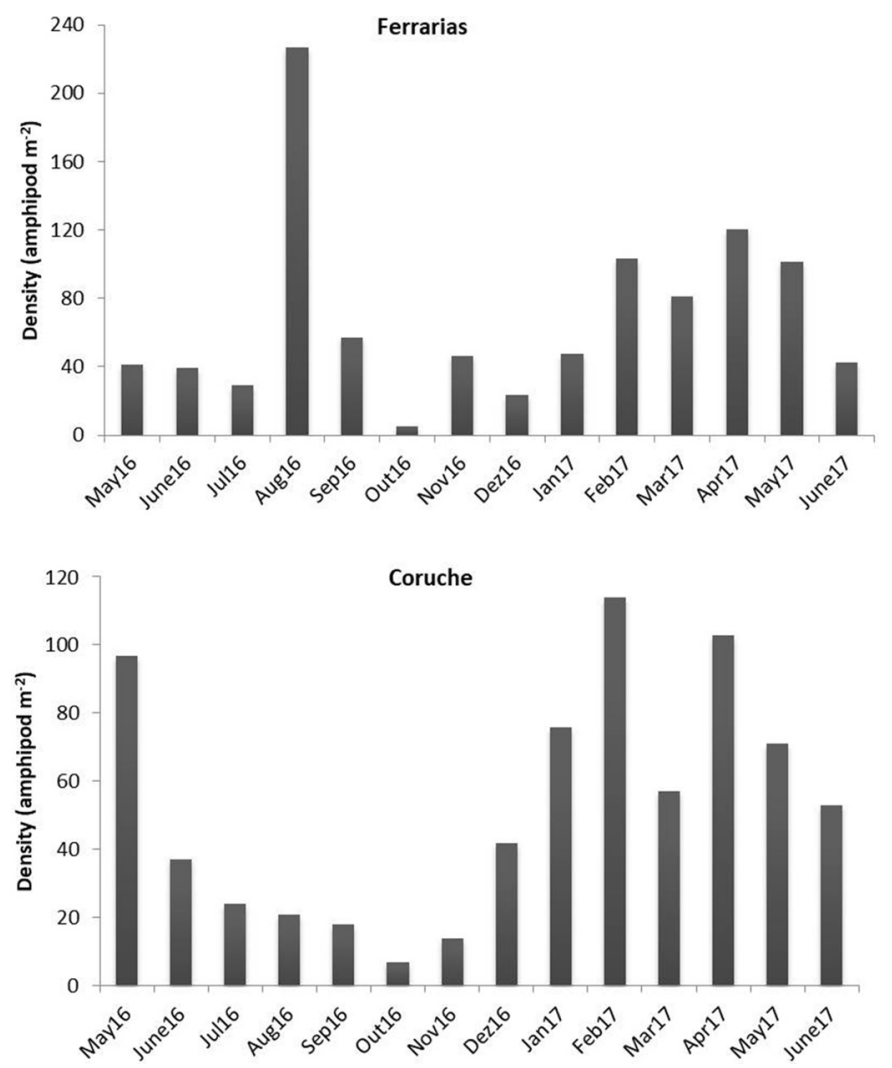

Fig. 1. Density of amphipods (amphipod number per square meter) in Coruche and Ferrarias.

In general, and for almost every month, the proportion of females was higher than males for both locations (Fig. 2). In Ferrarias we obtained an overall proportion of 0.76 females to 0.24 males and in Coruche the total proportion was 0.63 females to 0.37 males (Fig. 2). Regarding the total proportion of females with eggs, this was 0.11 in Coruche and 0.05 in Ferrarias. The total proportion of females with embryos was 0.01 for both Coruche and Ferrarias (Fig. 2).

In Ferrarias females with eggs occur from January to June and September to December, with higher incidence from January to June and in December. Females with embryos, occur in February, March, and June with a greater incidence in May. In Coruche, we found females with eggs from March to July and in October, with a higher incidence from March to June. Females with embryos occur in the months of March to June, especially in March.

For Coruche, a total of 559 eggs were counted with an average of 10.96 per female, in which the minimum size of females with eggs was $2.99 \mathrm{~mm}$. In Ferrarias there was a total of 2464 eggs with an average of 25.94 eggs per female, and the minimum size of females with eggs was $3.24 \mathrm{~mm}$. The total number of embryos observed in females for Coruche was 59, with an average of 9.38 embryos per female, and the minimum size of females with embryos was $5.08 \mathrm{~mm}$. For Ferrarias, the total number of embryos counted was 56 , with an average of 5.09 per female, and the minimum size of females with embryos was $6.72 \mathrm{~mm}$.
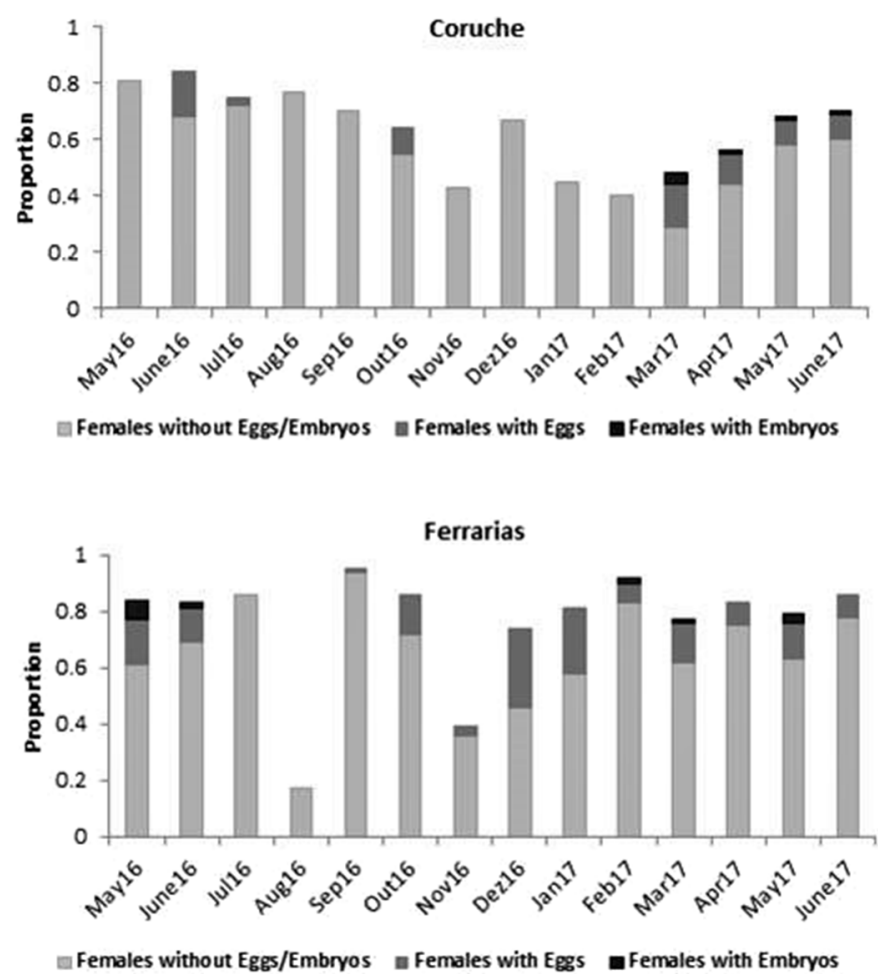

Fig. 2. Proportion of females in Coruche and Ferrarias.

Females have a greater range of size classes than males in all months and for both sampled locations (Fig. S2). We found that females are larger than males (approximately $1 \mathrm{~mm}$ ), both for Coruche (independent samples t-test: $p \leq 0.001$ ) and for Ferrarias (independent samples t- test: $\mathrm{p} \leq 0.001$ ). In Coruche we obtained a mean length of $5.56 \mathrm{~mm}$ (1.99-10.46 mm range) for females and $4.74 \mathrm{~mm}(2.99-7.99 \mathrm{~mm}$ range) for males. In the case of Ferrarias, the mean was $6.11 \mathrm{~mm}(1.82-14.54 \mathrm{~mm}$ range) for females and $4.51 \mathrm{~mm}(2.93-6.75 \mathrm{~mm}$ range) for males. Females with eggs had a mean length of $7.32 \mathrm{~mm}$ (2.99-9.91 mm range) in Coruche and $8.34 \mathrm{~mm}(3.24-12.58 \mathrm{~mm}$ range) in Ferrarias. In the case of the females with embryos, the mean length was $7.3 \mathrm{~mm}$ (5.08-8.48 mm range) in Coruche and $7.84 \mathrm{~mm}(6.72-9.6 \mathrm{~mm}$ range) in Ferrarias.

In Ferrarias, females have a greater range of size classes in January, $(2-15 \mathrm{~mm})$. Males have a greater range of size classes in May 2016, (2-6 mm), and in February, April and May 2017 (3-7 mm). In Coruche, females have a larger range of size classes in January $(3-11 \mathrm{~mm})$, March $(2-10 \mathrm{~mm})$ and April $(3-11 \mathrm{~mm})$. Males have a greater range of size classes in January (3-7 mm). For both males and females, from Coruche and Ferrarias, October presents the smallest range of size classes.

Figure 3 presents the cohorts for females and males from Ferrarias. For females we tracked a cohort from May to October 2016, with an average growth rate of $0.80 \mathrm{~mm} / \mathrm{month}$. A male cohort was tracked from February to June 2017, with an average growth rate of $0.49 \mathrm{~mm} / \mathrm{month}$. Male and female cohorts for Coruche are represented in Figure 3. However, it is not possible, neither for males nor females, to track the growth rate for any of the cohorts. 

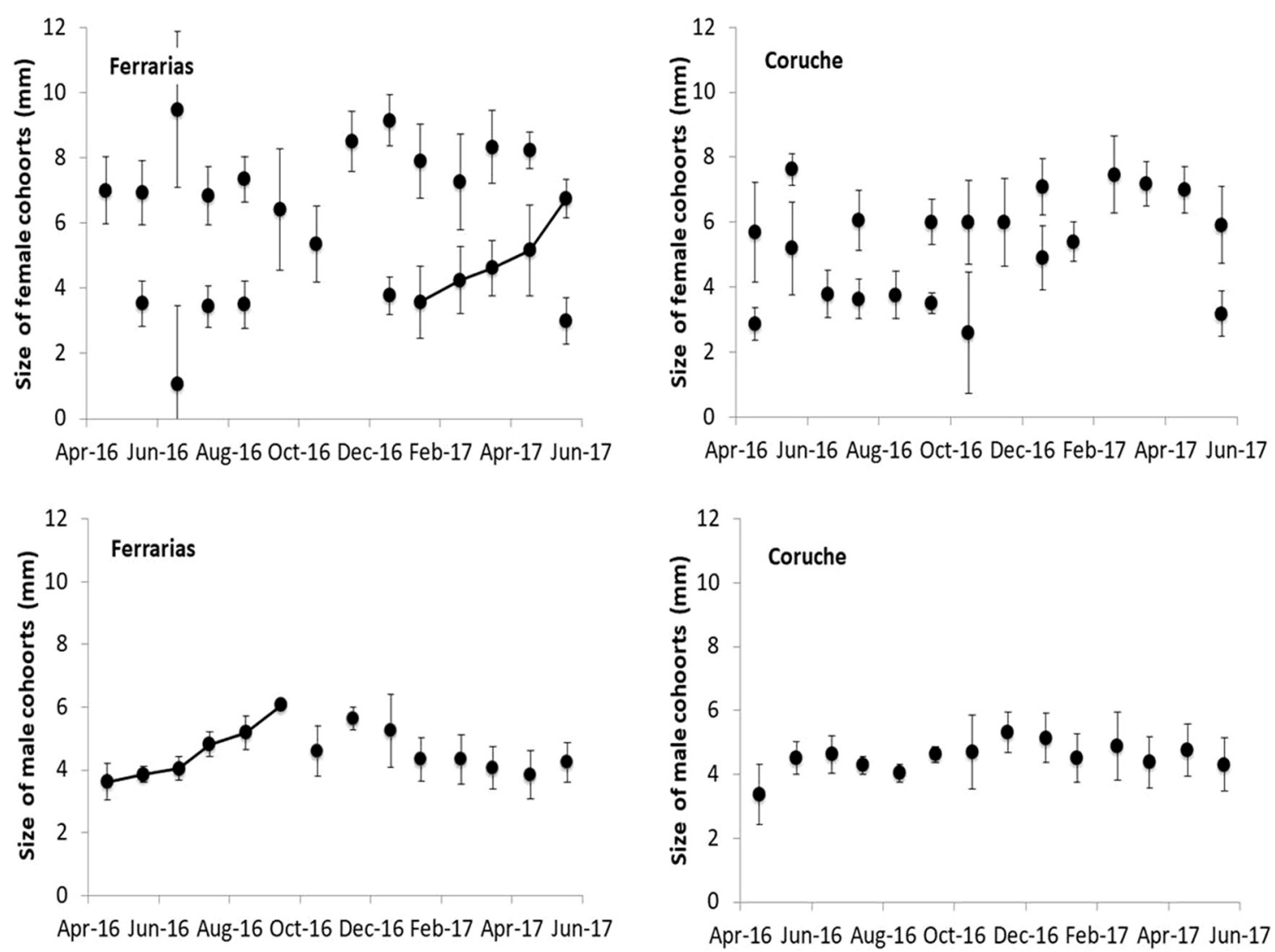

Fig. 3. Male and female cohorts detected in Ferrarias and in Coruche. A tracked cohort, which is a sequence of the average cohort size over the months, is represented in the charts from Ferrarias.

The proportion of males and females differs in Coruche (Chi-square test: $\mathrm{x}^{2}=104.013$, d.f. $\left.=13 ; \mathrm{p}<0.001\right)$ and in Ferrarias (Chi-square test: $\mathrm{x}^{2}=272.447$, d.f. $=13$; $\mathrm{p}<0.001$ ). The proportion of females along the year was significantly different in Ferrarias and Coruche (Wilcoxon test: $Z=-2.355$; $\mathrm{p}<0.05)$, which was higher for Ferrarias than for Coruche. All physical and chemical variables were significantly different in Ferrarias and Coruche along the year, according to a Wilcoxon test $\left(\mathrm{O}_{2}: \mathrm{Z}=-3.040, \mathrm{p}=0.002\right.$; water depth: $\mathrm{Z}=-2.806$, $\mathrm{p}=0.005 ;$ turbidity: $\mathrm{Z}=-2.803 ; \mathrm{p}=0.005$; conductivity: $\mathrm{Z}=-3.181 ; \quad \mathrm{p}=0.001 ; \quad$ temperature $\left({ }^{\circ} \mathrm{C}\right): \mathrm{Z}=-2.552$; $\mathrm{p}=0.011 ; \mathrm{pH}: \mathrm{Z}=-2.621 ; \mathrm{p}=0.009)$ (Fig. S3).

In Coruche, depth presents a greater amplitude of variation, attaining larger values than in Ferrarias (Fig. S3). In the case of dissolved $\mathrm{O}_{2}$, it is in Ferrarias that there is a higher variation. As for turbidity, it is in Coruche that there is a greater variation. Ferrarias presents a greater variation of the conductivity, however, values are higher for Coruche. In the case of the temperature, the variation for Ferrarias and Coruche is practically the same, being slightly higher in Ferrarias. Finally, $\mathrm{pH}$ presents an identical range of variation in both locations.

In Coruche (Fig. S4) maximum water temperature varied between 7 and $38^{\circ} \mathrm{C}$, while the average temperature varied among 6 and $26^{\circ} \mathrm{C}$ and finally the minimum temperature varied between 6 and $25^{\circ} \mathrm{C}$. In Ferrarias it was not possible to measure continuously the water temperature during the sampling period, since the logger placed there disappeared.
Nevertheless, water temperature values measured during sampling varied from 6 to $38^{\circ} \mathrm{C}$, with a mean value of $16^{\circ} \mathrm{C}$.

\subsection{Species distribution analysis}

In 2014 only 10 points were identified in the Tagus river basin with the presence of Crangonyx pseudogracilis (Banha et al., 2018), occupying an area of $579.13 \mathrm{~km}^{2}$. Currently, the distribution area has increased in Portugal, no longer being restricted to a small part of the Tagus basin and now it includes a large part of the Tagus river basin, with an area of 13055.46 $\mathrm{km}^{2}$. Furthermore, we are aware, through the analysis of amphipod samples provided by other research teams, that this species reached the north (Douro river basin and Ave river basin) and south (a small basin in the south-west: ribeira do Cavaleiro; Cavaleiro, Odemira) of the country. Knowing that the distribution area of the exotic species in the Tagus and west basins increased by $12476.33 \mathrm{~km}^{2}$ in $5 \mathrm{yr}$, it has an approximate diffusion coefficient (D) of $2495.27 \mathrm{~km}^{2} /$ year. By calculating the distance from the furthest new point (2019) to the old point (2014) closest to that, we obtained an approximate spread rate $(c)$ of $26.06 \mathrm{~km} /$ year. Knowing the diffusion coefficient (D) and the spread rate $(c)$, the intrinsic growth rate (r) was estimated at $0.07 /$ year.

Of the 57 sites sampled by our team in the Tagus and west area, the presence of Crangonyx pseudogracilis was found in 28 locations and the presence of the native species, genus 


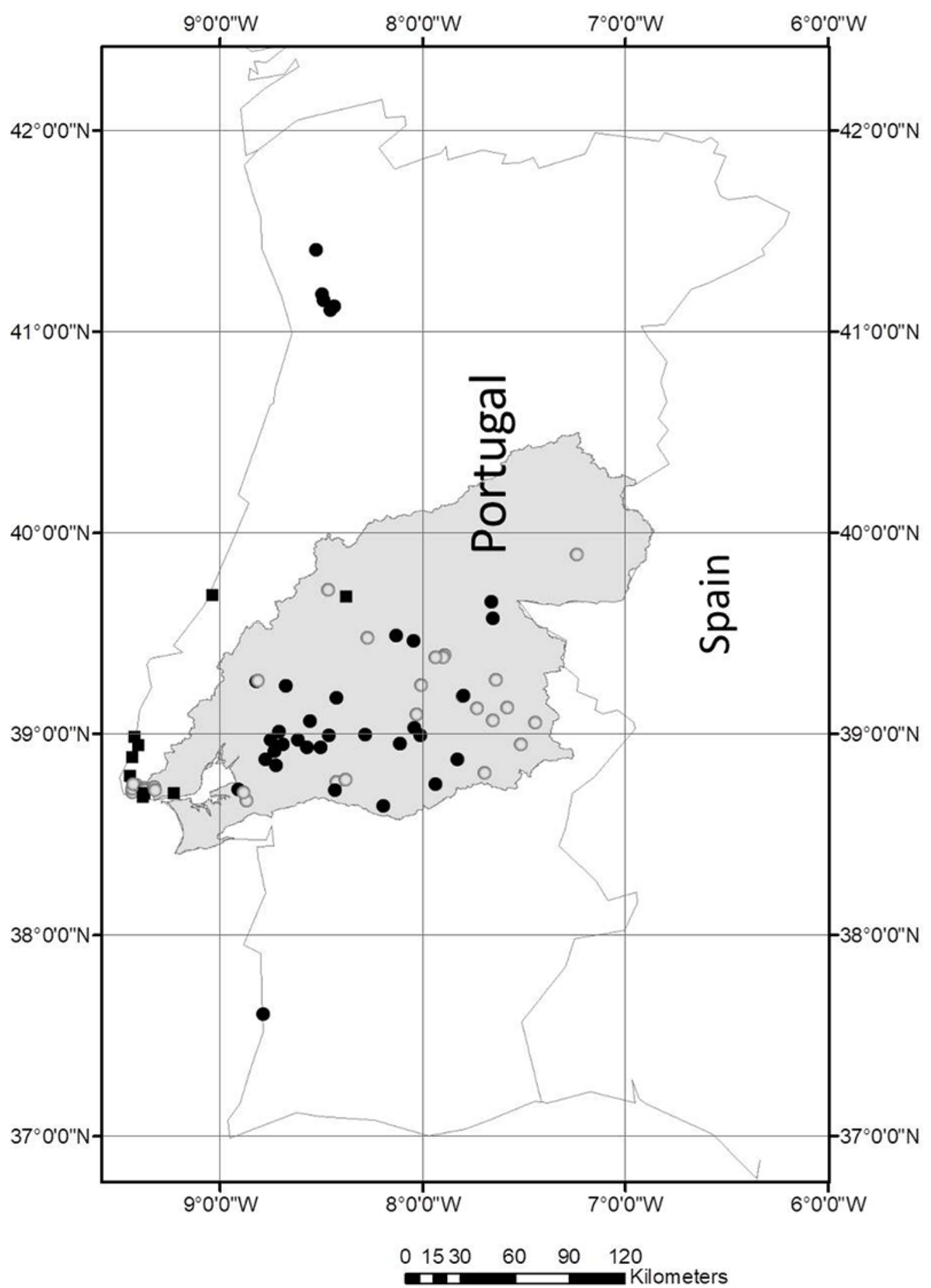

Fig. 4. Map of the current distribution of Crangonyx pseudogracilis, in Portugal. Black circles represent the points with Crangonyx pseudogracilis. White circles represent points without amphipods. Black squares represent points with native species (genus Echinogammarus). Grey area indicates the Tagus river basin in Portugal.

Echinogammarus, was detected in 8 points. Regarding the 18 points corresponding to the samples provided by other research teams, the presence of Crangonyx pseudogracilis was detected in 8 of these points and in 2 of them native amphipods (genus Echinogammarus) were found. However, there was no overlap between the exotic species and the native species for any of the mapped locations (Fig. 4).

\section{Discussion}

This study allowed us to better understand the biology of Crangonyx pseudogracilis and to follow the expansion of this exotic freshwater amphipod in Portugal, showing a great increase in its distribution area in relation to what was observed in 2014. We found that Crangonyx pseudogracilis 
females are larger than males, approximately $1.2 \mathrm{~mm}$ larger in Ferrarias and $0.85 \mathrm{~mm}$ in Coruche. This is in line with Henry and Tarter (1997), but in their case the difference was $3 \mathrm{~mm}$. This species reproduces in Ferrarias during most of the year (December to June), but in Coruche only from March to July. We also found that the density of amphipods decreases from May to October and increases from November to April. Our results, regarding the reproduction season in Ferrarias and the fact that the density of amphipods oscillates during the year, are in accordance with the studies in New York, by DiSalvo (2006; DiSalvo and Haynes, 2015).

We found that in the months with more amphipods, the temperatures were lower. More precisely, the months with temperatures above $12^{\circ} \mathrm{C}$ showed a lower density of captured amphipods than the months with temperatures below $12^{\circ} \mathrm{C}$. The most likely hypothesis that can explain this is that the optimal temperature is important for the survival and reproduction of amphipods. This species seems to prefer lower than higher temperatures, so this will be reflected in a greater or lesser population density, respectively. Another hypothesis is that, when amphipods are subjected to higher temperatures this results in a faster growth rate, which also leads to a faster sexual maturation and also resulting in shorter longevity (Biorede, 2020), which in a way may be related to the hypothesis previously presented. In contrast, amphipods subjected to lower temperatures have longer longevity since they have a slower growth rate, which results in a slower sexual maturity (Biorede, 2020). According to Brown et al. (2015) the time between moults depends mainly on the temperature. Longer intermoult periods correspond to slower growth rate and this occurs at low temperatures. In contrast shorter intermoult periods correspond to higher growth rates, and this occurs at high temperatures. However, amphipods are not only subjected to temperature variations, but also to many other variables such as predation, food availability, $\mathrm{pH}$, water depth, dissolved oxygen, conductivity and turbidity, and changes in environmental conditions can affect the densities of Crangonyx pseudogracilis (Brown et al., 2015).

According to the "Atlas of the wintering and migratory birds in Portugal" (2018), most water birds, present in our sampling sites, spend the winter there and then migrate to their nesting grounds. It should be noted that in our study the density of amphipods increases from November to April and decreases from May to October. When we compare the density of amphipods with the density of water birds, we realize that water bird abundance and density of amphipods seem to be temporally matched. Taking into account the experiences of Rachalewski et al. (2013), in which water birds are considered an important mean of dispersion of amphipods, this reinforces the potential risk of birds as a dispersion vector for this exotic species. Another important dispersion vector are dip nets used by fishermen to capture live bait or sometimes fish. Based on the studies by Banha et al. (2017), large amphipod densities and intense fishing activity coincide during May. Moreover, the distances reported in that study suggest that this vector could disperse $C$. pseudogracilis to much greater distances than birds.

It was noticed that the proportion of females was higher than that of males. Female-skewed sex ratio is common in crangonyctids, as shown by the studies of Dickson and
Holsinger (1981), with Crangonyx antennatus, and CopilasCiocianu and Boros (2016), with Synurella ambulans. Yet some environmental and biotic factors, could also have contributed for that, for example, a greater susceptibility of one of the genders to predation, which is directly related to the difference in sizes and behaviour. Although females of Crangonyx pseudogracilis are larger than males, males must find females to mate, thus being more exposed to predators (Jacobucci and Leite, 2006; Castiglioni et al., 2016). Additionally, a study by Watts et al. (2002) revealed that the exposure of amphipods to certain chemicals present in the residual water, such as $17 \alpha$ - ethinylestradiol or also known as environmental estrogen (EE), can favour females more than males, resulting in a marked difference in proportions between the genders. These factors could also act in our sampling locations. It is possible that in Ferrarias the proportion of males may be largely affected by the presence of predatory fish, such as pumpkinseed (Lepomis gibossus) and largemouth bass (Micropterus salmoides), while in Coruche, the major factor may be agriculture and untreated wastewaters pollution.

For both locations, females reached a greater length than males and this is not uncommon for amphipods. This result was also obtained in the study of Copilas-Ciocianu and Boros (2016), with Synurella ambulans, which suggests that this difference in size may be associated with mating behaviour, since pre-mating does not occur in these species. Another explanation, according to Kinne (1959) and Sheader (1983) is that males tend to select larger females since the female size is positively related to the number of eggs they can carry in their pouches. Also, the fact that females may pass through a larger number of moults, thus reaching a larger size than males and certain environmental conditions may benefit the growth of females more than that of males (Biorede, 2020). We observed that females also have a higher growth rate than males and this is in line with the studies of Sprules (1967), with Crangonyx richmondensis laurent and Devin et al. (2004), with Dikerogammarus villosus in France. We also found that the average growth rate estimated in our study $(0.80 \mathrm{~mm} / \mathrm{month}$ for females and $0.49 \mathrm{~mm} / \mathrm{month}$ for males) is low but in line with studies such as the one by Brown et al. (2015) in Antarctica, with Paramoera walkeri $(0.84 \mathrm{~mm} / \mathrm{month})$.

The reproduction season of Crangonyx pseudogracilis differed between locations. Additionally, its fecundity also differed, since in Ferrarias there was an average of 25.94 eggs per female, while in Coruche these values were much lower, with an average of 10.96 eggs per female. The strategy in Ferrarias seems to be to produce more eggs per reproductive female and to enlarge the recruitment period but to have a lower proportion of reproductive females. These differences can be explained by different habitat characteristics (temporary stream vs. natural lake), which results in different meso-habitat characteristics at each site (water depth, type of substrate, type of vegetation and speed of water flow) and also different values of the physical and chemical variables $(\mathrm{pH}$, water depth, oxygen level, conductivity, temperature and turbidity). These differences may be reflected in unequal behaviour, growth rate and reproduction seasons for amphipod populations present in each of the sites. In Coruche, the habitat is always the same, a natural lake, which makes it more stable. However, in Ferrarias the habitat is a temporary river, which flows during the winter 
and is reduced to pools in the summer, which makes it less stable. When young females from other species are faced with favourable environmental conditions, they can reach sexual maturity in just one month (Biorede, 2020), which explains why we find $2.99 \mathrm{~mm}$ long females with eggs only in Coruche and $3.24 \mathrm{~mm}$ in Ferrarias.

Finally, in comparison with the distribution of Crangonyx pseudogracilis reported for 2014, there was a very large increase in the Tagus and West hydrographic zone. Additionally, it is also present in the north and south of the country, apparently involving long-distance dispersal mechanisms. However, the total area that it occupies now it is not yet known, and additional sampling effort is needed in the north and south of Portugal. Despite the increment of the distribution area, no overlap was yet detected between native amphipod species occurrence and this exotic species. It was found that the area occupied by Crangonyx pseudogracilis is increasingly approaching the area where there are native species of the genus Echinogammarus. This is especially notorious for the Mondego river basin and for the western Portuguese river basins.

Despite predictable future native/exotic species distribution overlap, $C$. pseudogracilis may not have a negative impact on native species, both coexisting in the same habitat. Laboratory experiments have shown that during short term interactions with Echinogammarus meridionalis there was no effect on the survival rate of the native species when it is in the presence of the exotic. Additionally, the species is apparently not carrying transmissible microsporidian parasites (Banha et al., 2018) and there was no short-term competition for food, nor predation, in the absence of food, of the native by the exotic (Gama et al., 2017). Crangonyx pseudogracilis inhabits a wide range of freshwater habitats and it is more commonly found in shallow ponds and more polluted areas (Grabowski et al., 2012). Echinogammarus meridionalis, on the other hand, prefers well-oxygenated, less polluted areas (MacNeil et al., 2001). These differences may allow the coexistence of both species in the same place but in different micro-habitats (MacNeil and Dick, 2014). However, there is still the possibility of having a negative impact on native species through long-term competition either for food or for habitat. This could lead to the exclusion of native species from their current area of distribution or, eventually, to their extinction. If the latter is detected, then it will be necessary to apply measures to control the spread of this invasive species or to promote the conservation of native amphipod species.

\section{Supplementary Material}

Supplementary Figure S1. Histograms of males and females for each month in each of the sampled location.

Supplementary Figure S2. Boxplot of the physical-chemical variables (Depth (cm), $\mathrm{O}_{2}$ (ppm), Turbidity (NTUs), Conductivity $(\mathrm{mS})$, Temperature $\left({ }^{\circ} \mathrm{C}\right)$ and $\left.\mathrm{pH}\right)$ in Coruche and Ferrarias. Supplementary Figure S3. Water temperature $\left({ }^{\circ} \mathrm{C}\right)$ in Coruche.
Supplementary Figure S4. Pictures of sampling sites habitat. A- Coruche; B- Ferrarias.

The Supplementary Material is available at https://www.kmaejournal.org/10.1051/kmae $/ 2021001 / \mathrm{olm}$.

Acknowledgements. This study was financially supported by LIFE Invasaqua project (Aquatic Invasive Alien Species of freshwater and Estuarine Systems: Awareness and Prevention in the Iberian Peninsula) (LIFE17 GIE/ES/000515) funded by the EU LIFE program and by the strategic plan of MARE Marine and Environmental Sciences Centre (UID/MAR/ 04292/2019). We thank the Administration of the Tagus and West Hydrographic Region (ARHTO) for the locations provided, where amphipods were present, in the Tagus and West area. We also thank Maria José Caramujo, Maria João Feio, Maria Margarida Machado, Sara Faria (EMAC) and João Pinto for amphipod samples. The laboratory work had the technical support of Maria José Barão. The field sampling had the meaningful help of Silvina dos Santos.

\section{References}

Anastácio P, Marques M, Águas M, Wójcik-Fudalewska D, NormantSaremba M. 2018. Population structure and reproductive status of the invasive Eriocheir sinensis (Decapoda, Varunidae) in the Tagus estuary (Portugal). Limnetica 37: 47-59.

Atlas das Aves Invernantes e Migradoras de Portugal. 2018. http:// www.labor.uevora.pt/pt/ja-esta-disponivel-o-atlas-das-aves-inver nantes-e-migradoras-de-portugal/ (accessed May 2020).

Aylward B, Bandyopadhyay J, Belausteguigotia JC, Borkey P, Cassar A, Meadors L, et al. 2005. Chapter 7-Freshwater ecosystem services. Ecosystems and Human Well-Being: Policy Responses. Millennium Ecosystem Assessment 3: 213-256.

Banha F, Anastácio PM. 2015. Live bait capture and crayfish trapping as potential vectors for freshwater invasive fauna. Limnologica 51: 63-69.

Banha F, Diniz A, Anastácio PM. 2017. The role of anglers' perceptions and habits in biological invasions: perspectives from the Iberian Peninsula. Aquatic Conservation: Marine and Freshwater Ecosystems 27: 51-64.

Banha F, Anastácio PM, Rachalewski M, Bacela-Spychalska K, Grabowski M. 2018. Enhanced fecundity and parasite release in the first amphipod invader on the Iberian Peninsula. Knowl Manag Aquat Ecosyst 419: 21.

Biorede. 2020. Corophium multisetosum. http://www.biorede.pt/ index4.htm (accessed April 2020).

Brown KE, King CK, Harrison P.L. 2015. Reproduction, growth and early life history of the Antarctic gammarid amphipod Paramoera walkeri. Polar Biol 38: 1583-1596.

Castiglioni DDS, Ozga AV, Rodrigues SG, Bueno AADP. 2016. Population dynamics of a freshwater amphipod from South America (Crustacea, Amphipoda, Hyalellidae). Nauplius 24 (e2016028): 1-8.

Copilaş-Ciocianu D, Boroş BV. 2016. Contrasting life history strategies in a phylogenetically diverse community of freshwater amphipods (Crustacea: Malacostraca). Zoology 119: 21-29. 
Crawford GI. 1937. An amphipod, Eucrangonyx gracilis S.I. Smith, new to Britain. Nature 139: 327.

Devin S, Piscart C, Beisel JN, Moreteau JC. 2004. Life history traits of the invader Dikerogammarus villosus (Crustacea: Amphipoda) in the Moselle River, France. Int Rev Hydrobiol 89: 21-34.

Dick JTA, Faloon SE, Elwood RW. 1998. Active brood care in an amphipod: influences of embryonic development, temperature and oxygen. Anim Behav 56: 663-672.

Dick JTA, MacNeil C, Anderson R. 1999. The Distribution of Crangonyx pseudogracilis (Bousfield, 1958) (Crustacea: Amphipoda) in Northern Ireland, with Notes on Its Ecology and Behaviour. Irish Nat J 26: 236-240.

Dickson GW, Holsinger JR. 1981. Variation among populations of the troglobitic amphipod crustacean Crangonyx antennatus Packard (Crangonyctidae) living in different habitats, III: population dynamics and stability. Int J Speleol 11: 5.

Disalvo BC. 2006. Colonization and Persistence of the Freshwater Amphipod, Crangonyx pseudogracilis, in Temporary Ponds: Aspects of its Ecology, Resistance to Desiccation, and Dispersal Abilities. Thesis (Environmental Science and Ecology), The College At Brockport State University Of New York, New York.

DiSalvo BC, Haynes JM. 2015. Colonization and persistence of Crangonyx pseudogracilis (Bousfield 1958) in temporary pools. Freshw Sci 34: 547-554.

Dobson M. 2012. Identifying invasive freshwater shrimps and isopods. Ambelside: Freshwater Biological Association, pp. 1-32.

Ferreira MT. 1994. Aquatic and marginal vegetation of the River Divor and its relation to land use. Int Ver Theo Angew Limnol Verh 25: 2309-2315.

Gama M, Marquéz L, Banha F, Anastácio P. 2017. Coexistence patterns between the invasive amphipod Crangonyx pseudogracilis and native Echinogammarus meridionalis: a laboratory approach. Fundam Appl Limnol 190: 133-140.

Gledhill T, Sutcliffe DW, Williams WD. 1993. British freshwater Crustacea Malacostraca: a key with ecological notes. Ambleside Freshw Biol Assoc Sci Publ 52: 1-173.

Grabowski M, Rachalewski M, Banha F, Anastacio P. 2012. Crangonyx pseudogracilis Bousfield, 1958-the first alien amphipod crustacean in freshwaters of Iberian Peninsula (Portugal). Knowl Manag Aquat Ecosyst 404: 11.

Guerra MT, Gaudêncio MJ. 2016. Identificação das espécies de crustáceos não indígenas da costa portuguesa. (http://biomarpt. ipma.pt/pdfs/5382CURSO12_Guia_tecnico.pdf).

Henry AL, Tarter DC. 1997. Ecological observations of Crangonyx pseudogracilis Bousfield (Crustacea: Amphipoda) from the Green Bottom Wildlife Management Area, Cabell County, West Virginia. Proc West Virginia Acad Sci 69: 10.

Holland DG. 1976. Distribution of freshwater Malacostraca in area of Mersey and Weaver river authority. Freshw Biol 6: $265-276$.

Holmes JMC. 1975. Crangonyx pseudogracilis Bousfield a freshwater amphipod new to Ireland. Irish Nat J 18: 225-226.

Hynes HBN. 1955. The reproductive cycle of some freshwater Gammaridae. J Anim Ecol 24: 352-387.

Jacobucci GB, Leite FPP. 2006. Biologia populacional das espécies de Ampithoidae (Crustacea, Amphipoda) associadas a Sargassum filipendula (Phaeophyta, Fucales) na Praia da Fortaleza, Ubatuba, São Paulo, Brasil. Rev Bras Zool 23: 1207-1216.
Josens G, Vaate AB de, Usseglio-Polatera P, Cammaerts R, Chérot F, Griseg F, Bossche J-PV. et al. 2005. Native and exotic Amphipoda and other Pericarida in the River Meuse: new assemblages emerge from a fast changing fauna. Hydrobiologia, 542: 203-220.

Jourdan J, Westerwald B, Kiechle A, Chen W, Streit B, Klaus S, Oetken M, Plath M. 2016. Pronounced species turnover, but no functional equivalence in leaf consumption of invasive amphipods in the river Rhine. Biol Invasions 18: 763-774.

Katsanevakis S, Gatto F, Zenetos A, Cardoso AC. 2013. How many marine aliens in Europe. Manag Biol Invasions 4: 37-42.

Kinne O. 1959. Ecological data on the amphipod Gammarus duebeni. Veroff Inst Meeresforsch Bremerh 6: 177-202.

Lockwood J, Hoopes M, Marcheti M. 2007. Invasion ecology. Blackwell Publishing, p. 312.

MacNeil C, Dick JTA. 2014. Physicochemical tolerance, habitat use and predation are drivers of patterns of coexistence and exclusion among invasive and resident amphipods. Freshw Biol 59: 1956-1969.

MacNeil C, Montgomery WI, Dick JTA, Elwood RW. 2001. Factors influencing the distribution of the native and introduced Gammarus species in Irish river systems. Arch Hydrobiol 151: 353-368.

Maitland PS, Adams CE. 2001. Enhanced biodiversity or a threat to native species? Glasg Nat 23: 26-34.

Pinkster S. 1973. The Echinogammarus berilloni group a number of predominantly Iberian Amphipod species (Crustacea). Bijd Dierkunde 43: 1-39.

Pinkster S. 1993. A revision of the genus Echinogammarus Stebbing, 1899, with some notes on related genera (Crustacea, Amphipoda). Memorie del Museo Civ. Stor. Nat. (IIa ser) 10: $1-185$.

Pinkster S, Platvoet D. 1983. Further observations on the distribution and biology of two alien amphipods, Gammarus tigrinus (Sexton, 1939), and Crangonyx pseudogracilis Bousfield, 1958, in the Netherlands (Crustacea, Amphipoda). Bull Zool Mus 9: $153-162$.

Pinkster S, Dieleman J, Platvoet D. 1980. The present position of Gammarus tigrinus Sexton, 1939, in the Netherlands, with the description of a newly discovered amphipod species, Crangonyx pseudogracilis (Bousfield, 1958) (Crustacea, Amphipoda). Bull Zool Mus 7: 33-38.

Piscart C, Mermillod-Blondin F, Maazouzi C, Merigoux S, Marmonier P. 2011. Potential impact of invasive amphipods on leaf litter recycling in aquatic ecosystems. Biol Invasions 13: 2861-2868.

Rachalewski M, Banha F, Grabowski M, Anastácio P. 2013. Ectozoochory as a possible vector enhancing the spread of an alien amphipod Crangonyx pseudogracilis. Hydrobiologia 717: 109-117.

Sheader M. 1983. The reproductive biology and ecology of Gammarus duebeni (Crustacea: Amphipoda) in southern England. J Mar Biol Assoc U.K. 63: 517.

Silfverberg H. 1999. A provisional list of Finnish Crustacea. Memoranda Soc Pro Fauna Fl Fenn 75: 15-37.

Slothouber Galbreath JG, Smith JE, Becnel JJ, Butlin RK, Dunn AM. 2009. Reduction in post-invasion genetic diversity in Crangonyx pseudogracilis (Amphipoda: Crustacea): a genetic bottleneck or the work of hitchhiking vertically transmitted microparasites? Biol Invasions 12: 191-209. 
Sparre P, Ursin E, Venema SC. 1992. Introduction to Tropical Fish Stock Assessment. Part 1- Manual. FAO Rome, Vol. 306, p. 376.

Sprules WG. 1967. The life cycle of Crangonyx richmondensis laurentianus Bousfield (Crustacea: Amphipoda). Can J Zool 45: 877-884.

Sutcliffe DW, Carrick TR. 1981. Effect of temperature on the duration of egg development, and moulting and growth in juveniles of Crangonyx pseudogracilis (Crustacea, Amphipoda) in the laboratory. Freshw Biol 11: 511-522.

Tattersal WM. 1937. Occurrence of Eucrangonyx gracilis. Nature 139: 593
Väinölä R, Witt JDS, Grabowski M, Bradbury JH, Jazdzewski K, Sket B. 2007. Global diversity of amphipods (Amphipoda; Crustacea) in freshwater. Hydrobiologia, 595: 241-255.

Watts MM, Pascoe D, Carroll K. 2002. Population responses of the freshwater amphipod Gammarus pulex (L.) to an environmental estrogen, 17 $\alpha$-ethinylestradiol. Environ Toxicol Chem Int J 21: 445-450.

Zar JH. 1999. Biostatistical analysis. New Jersey: Prentice Hall, pp. $1-663$.

Zhang J, Holsinger JR. 2003. Systematics of the Freshwater Amphipod Genus Crangonyx (Crangonyctidae) in North America. Virginia Museum of Natural History 6: 1-274.

Cite this article as: Correia D, Banha F, Gama M, Anastácio PM. 2021. Population dynamics and expansion of Crangonyx pseudogracilis, a potentially invasive amphipod. Knowl. Manag. Aquat. Ecosyst., 422, 8. 